\title{
STUDY OF THE EFFECT OF ECHINOPHORA PLATYLOBA ETHANOLIC EXTRACT ON SURVIVAL OF LISTERIA MONOCYTOGENES IN LIGHVAN CHEESE DURING RIPENING TIME
}

\author{
Siavash Ghaderi ${ }^{1}$, Saman Mahdavi², Alireza Yousefi ${ }^{3}$ \\ ${ }^{1}$ Department of Food Engineering, Maragheh Branch, Islamic Azad University, \\ Maragheh, Iran \\ ${ }^{2}$ Department of Microbiology, Maragheh Branch, Islamic Azad University, \\ Maragheh, Iran \\ ${ }^{3}$ Department of Chemical Engineering, Faculty of Engineering, \\ University of Bonab, Bonab, Iran
}

Received 8 August 2020; Received in revised form 9 January 2021; Accepted 12 January 2021

\begin{abstract}
Listeria monocytogenes is one of the most frequent foodborne bacteria that can be transmitted through dairy products. The demand for replacing chemical preservatives with natural compounds has increased recently. The aim of this study was to investigate the effect of Echinophora platyloba DC ethanolic extract on the survival of L. monocytogenes in Lighvan cheese during ripening time. Three concentrations of E. platyloba ethanolic extract $(0,0.5,1$ and $1.5 \%)$ were added to raw milk at the beginning of Lighvan cheese manufacture, and the population of L. monocytogenes was counted on days 15 , 30, 60 and 90. Furthermore, the $\mathrm{pH}$ and salt concentration of Lighvan cheese were evaluated in these periods. The results showed that an increase in the concentration of ethanolic extract, as well as the ripening time of Lighvan cheese, resulted in a significant decrease $(\mathrm{p}<0.05)$ in the levels of L. monocytogenes $(\mathrm{cfu} / \mathrm{g})$. Moreover, the logarithm of the L. monocytogenes population $(\log \mathrm{cfu} / \mathrm{g})$ was significantly decreased $(\mathrm{p}<0.05)$ as the concentration of the added ethanolic extract was enhanced over the ripening time, but no significant changes in $\mathrm{pH}$ and salt concentration were observed in Lighvan cheese ( $\mathrm{p}>0.05)$. It was found that the optimal concentration of E. platyloba ethanolic extract for the complete inhibition of L. monocytogenes was $1-1.5 \%$ following 90 days of the ripening.
\end{abstract}

Key words: Echinophora platyloba, ethanolic extract, Lighvan cheese, Listeria monocytogenes

\section{INTRODUCTION}

Listeria monocytogenes is a Gram-positive, non-sporing, bacilliform bacterium that is relatively heat-tolerant, widely dispersed in nature, and can be found in raw milk. As a psychrotroph, this bacterium grows well in the refrigerator during storage (1). L. monocytogenes causes listeriosis which is a worldwide zoonotic disease. It enters the body by

Corresponding author: Dr. Saman Mahdavi, $\mathrm{PhD}$

E-mail address: S.mahdavi@iau-maragheh.ac.ir

Present address: Department of Microbiology, Maragheh Branch, Islamic

Azad University, Maragheh, Iran

Phone: +98 9144150454

Copyright: (C) 2021 Ghaderi S. This is an open-access article published under the terms of the Creative Commons Attribution License which

permits unrestricted use, distribution, and reproduction in any medium, provided the original author and source are credited.

Competing Interests: The authors have declared that no competing interests exist.

Available Online First: 1 March 2021

Published on: 15 March 2021

https://doi.org/10.2478/macvetrev-2021-0012 contaminated foods such as cheese and vegetables, causing meningoencephalitis, rarely affecting other organs. Neonates, pregnant women, the elderly and immunosuppressed people are considered to be a risk group for this disease (2). Traditional cheeses can be considered as one of the main sources of pathogens due to the unsanitary production and storage conditions. The prevalence of $L$. monocytogenes in cheeses produced from raw milk compared to those produced from pasteurized milk is higher (3). Furthermore, the prevalence of $L$. monocytogenes in soft and semi-soft cheeses due to their high moisture content is higher than in hard cheeses (4).

It is reported that about $1-5 \%$ of food-borne intoxications are associated with the consumption of milk and dairy products, among which 53\% have been due to the consumption of contaminated cheeses (5). The presence of $10^{3}-10^{4} \mathrm{cfu}$ of L. monocytogenes per gram of cheese can cause 
disease. However, in people with weakened immune systems, the infectious dose is probably less than 1,000 bacterial cells (6). Khedmati Morasa et al. (7) showed that $2.3 \%$ of Lighvan cheese in Qazvin (central part of Iran) was contaminated with L. monocytogenes. Lighvan cheese is a white brine cheese that is usually made of cow, buffalo, goat milk, or its mixture (8). Raw milk is used in the traditional production of Lighvan cheese. Annually, at Lighvan village (located in the Northwest of Iran), nearly 3,150 tons of Lighvan cheese are produced (8). In the traditional method of Lighvan cheese production, raw milk is coagulated by rennet, and the resulting clot after dehydration is cut into pieces. Then, salt is added and the pieces are put into cans, adding brine as well. Afterward, the produced cheeses are allowed to go through a ripening period of 3-12 months at $10{ }^{\circ} \mathrm{C}(9)$. Many stages of cheese production are performed manually using traditional equipment, thus increasing the risk of contamination with spoilage germs, especially animal, human (workers) and environmental pathogens. All these factors reduce the hygienic quality and shelf life of this product $(8,10)$. The most effective way of protecting dairy products from pathogenic germs could be a sufficient heat treatment, which is not widely accepted by rural producers due to its adverse effect on sensory properties and milk quality (11). Local cheeses are produced by heating below $50^{\circ} \mathrm{C}$, which is insufficient to kill most microbes (12). Due to the cultural habits of people to consume foods without chemical preservatives, the food industry utilizes plants as a source of antimicrobial and flavoring compounds (13). This alternative is a suitable solution to control pathogenic bacteria and increase food shelf life.

Echinophora platyloba DC is a native plant in Iran and is traditionally used as a food flavoring in yogurt and cheese $(14,15)$. Recently, the essential oils and extracts of this herb have been introduced in the dairy industry, yielding promising results as long-term preservative and flavoring agents in yogurt and cheese. Flavonoids and other phenolic compounds are widely distributed in plants having diverse biological effects: antioxidant, antimicrobial, anti-inflammatory and vasodilatory. Phenolic compounds in plant extracts with antioxidant properties can play an important role in preserving food products and maintaining human health (16). The aim of this study was to investigate the effect of various concentrations of E. platyloba ethanolic extract $(0-1.5 \%)$ on the survival of L. monocytogenes in Lighvan cheese during 90 days of ripening time.

\section{MATERIAL AND METHODS}

\section{Collection and identification of E. platyloba}

E. platyloba was purchased locally from a medical plant supplier in Maragheh city (Eastern Azarbaijan province, Northwest of Iran) and was transferred to the herbarium of Islamic Azad University, Maragheh Branch for identification.

\section{Ethanolic extraction}

The ethanolic extract was obtained by the maceration method. Twenty grams of E. platyloba was soaked in 1 liter of ethanol $80 \%$ (Merck, Germany) and the mixture was transferred to a shaker for $24 \mathrm{~h}$ at room temperature. Then, this mixture was filtered and desolvented with a rotary evaporator (Wiggens, Germany). The ethanolic extract was poured into a dark bottle and stored in a refrigerator at $4{ }^{\circ} \mathrm{C}$.

Evaluation of antimicrobial activity by microdilution method (In vitro)

Minimum inhibitory concentration (MIC) and minimum bactericidal concentration (MBC) methods were used for the determination of the antimicrobial effect of E. platyloba ethanolic extract. For this purpose, L. monocytogenes PTCC 1298 (provided by Iran industrial research organization) was cultured in sterile Brain Heart Infusion (BHI; Merck company, Germany) for 24 hours at $37^{\circ} \mathrm{C}$. The serial dilutions were prepared using Müller Hinton Broth medium (MHB; Merck company, Germany) from 20 to $0.039 \mathrm{mg} / \mathrm{ml}$. MIC test was performed by microdilution method. First, $100 \mu \mathrm{L}$ of MHB was added to each well (except for the first well). Then, $100 \mu \mathrm{L}$ of the ethanolic extract with a concentration of $20 \mathrm{mg} / \mathrm{ml}$ was poured into the first and second wells, and $100 \mu \mathrm{L}$ was transferred from the second well to the third well. This procedure was continued to the 10th well. Therefore, dilutions of 20 to $0.039 \mathrm{mg} / \mathrm{ml}$ of ethanolic extract were prepared. A $100 \mu \mathrm{l}$ of the fresh bacterial culture (the equivalent of concentration of $0.5 \mathrm{McFarland}$ test) was added to each well and incubated at $37^{\circ} \mathrm{C}$ for $24 \mathrm{~h}$. After $24 \mathrm{~h}$, the presence of turbidity (compared to the control row) indicated bacterial growth, whereas transparency indicated no bacterial growth. The lowest concentration in which no bacterial growth was observed was considered as MIC. A higher and a lower concentration than the MIC were selected and cultured in BHI agar medium and incubated at $37^{\circ} \mathrm{C}$ for $24 \mathrm{~h}$. The first plate associated with the well 
that did not show bacterial colony was considered as the ethanolic extract $\mathrm{MBC}(2.5 \mathrm{mg} / \mathrm{ml})$. The MBC was defined as the concentration in which no microorganism growth was observed (17, 18). All of the tests were repeated in three replicates and the means of the results were considered as $\mathrm{MIC}$ and MBC. Finally, three concentrations that were higher than MBC $(20 \mathrm{mg} / \mathrm{ml})$ were considered to be added to the raw milk.

\section{Analysis of raw milk}

The characteristics of raw cow milk were analyzed before the cheese making. Acidity was determined based on Dornic degree by the AOAC method (19). The amount of fat was measured by the Gerber method (20). The Kjeldahl method was considered for protein measurement (21).

Manufacture of Lighvan cheese and addition of ethanolic extract

Rennet was added to $1 \mathrm{~L}$ of raw milk together with $10 \mathrm{ml}$ of L. monocytogenes PTCC 1298 broth (the equivalent of turbidity of 0.5 McFarland test $\left.\left(1.5 \times 10^{8} \mathrm{cfu} / \mathrm{ml}\right)\right)$. The salt concentration for all the samples was adjusted to $6 \%(\mathrm{w} / \mathrm{v})$. Three concentrations of the ethanolic extract of E. platyloba $(0,0.5,1$ and $1.5 \%)$ were added to the samples. Sampling and microbial enumeration of the samples were performed at 15, 30, 60 and 90 days after the addition of rennet.

Enumeration of L. monocytogenes in Lighvan cheese

Ten grams of homogenized cheese were added to $90 \mathrm{ml}$ of sterile distilled water. The mixture was vortexed for 5 minutes. Then, serial dilutions of samples $\left(10^{-1}-10^{-7}\right)$ were prepared and cultured on Listeria Palcam Agar (Merck, Germany) containing potassium thiocyanate $(37.5 \mathrm{~g} / \mathrm{L})$ and nalidixic acid $(50 \mathrm{mg} / \mathrm{ml})$, and were incubated at $37{ }^{\circ} \mathrm{C}$ for $48 \mathrm{~h}$.
After the incubation period, microbial enumeration was performed.

\section{Evaluation of $\mathrm{pH}$ and salt concentration in} Lighvan cheese

At 15, 30, 60 and 90 days after rennet addition, the salt concentration and $\mathrm{pH}$ of the cheese were measured simultaneously with the L. monocytogenes enumeration of the samples.

\section{Statistical analysis}

Statistical analysis was performed in a $4 \times 4$ factorial experiment with a completely randomized design with four levels of E. platyloba ethanolic extract $(0,0.5,1$ and $1.5 \%)$ at four time intervals $(15,30,60$ and 90 days) with 3 replications per treatment. Statistical analysis was performed using SAS 9.2 software (2014) G1M procedure and mean comparisons were performed by Tukey test.

\section{RESULTS}

\section{Analysis of raw milk}

The characteristics of the raw milk were as follows: Acidity (\%) 16.5 \pm 0.0 , fat-free dry matter (\%) $11.13 \pm 0.00$, density $(\mathrm{g} / \mathrm{ml}) \quad 36.6 \pm 0.0$, fat $(\%)$ $1.55 \pm 0.00$ and protein $(\mathrm{g}) 3.47 \pm 0.00$.

\section{Assessment of MIC and MBC of E. platyloba ethanolic extract}

Both MIC and MBC of E. platyloba ethanolic extract were $2.5 \mathrm{mg} / \mathrm{ml}$.

L. monocytogenes enumeration, assessment of pH and salt concentration in Lighvan cheese

As it is evident from the results shown in Table 1, the logarithm of L. monocytogenes population ( $\log \mathrm{cfu} / \mathrm{g})$ was significantly decreased over the ripening time for the control samples $(\mathrm{p}<0.05)$.

Table 1. The effect of ripening time on $\mathrm{pH}$, salt concentration and L. monocytogenes population $(\log \mathrm{cfu} / \mathrm{g})$ in Lighvan cheese (control samples)

\begin{tabular}{lccc}
\hline Time (Days) & $\mathbf{p H}$ & Salt concentration $(\%)$ & L. monocytogenes population \\
\hline $\mathbf{1 5}$ & $4.965 \pm 0.107^{\mathrm{a}}$ & $4.283 \pm 0.439^{\mathrm{a}}$ & $5.736 \pm 0.116^{\mathrm{a}}$ \\
$\mathbf{3 0}$ & $4.890 \pm 0.092^{\mathrm{a}}$ & $4.008 \pm 0.080^{\mathrm{a}}$ & $5.835 \pm 0.103^{\mathrm{a}}$ \\
$\mathbf{6 0}$ & $4.985 \pm 0.114^{\mathrm{a}}$ & $4.042 \pm 0.077^{\mathrm{a}}$ & $3.841 \pm 0.076^{\mathrm{b}}$ \\
$\mathbf{9 0}$ & $4.771 \pm 0.209^{\mathrm{a}}$ & $4.117 \pm 0.024^{\mathrm{a}}$ & $1.914 \pm 0.045^{\mathrm{c}}$ \\
$\mathbf{S E M}$ & 0.097 & 0.195 & 0.283 \\
\hline
\end{tabular}

a-c: within a column, values not sharing the same superscript letter were considered as significantly different $(\mathrm{p}<0.05)$. SEM: Standard error of the mean. The reported mean for L. monocytogenes is logarithmic conversion 
Table 2. The effect of different levels of E. platyloba ethanolic extract on $\mathrm{pH}$, salt concentration and L. monocytogenes population ( $\log \mathrm{cfu} / \mathrm{g})$ in Lighvan cheese after 15 days of ripening

\begin{tabular}{lccc}
\hline Levels of ethanolic extract (\%) & $\mathbf{p H}$ & Salt concentration (\%) & L. monocytogenes population \\
\hline $\mathbf{0}$ & $4.965 \pm 0.107^{\mathrm{a}}$ & $4.283 \pm 0.439^{\mathrm{a}}$ & $5.736 \pm 0.116^{\mathrm{a}}$ \\
$\mathbf{0 . 5}$ & $4.870 \pm 0.051^{\mathrm{a}}$ & $3.975 \pm 0.100^{\mathrm{a}}$ & $4.501 \pm 0.176^{\mathrm{b}}$ \\
$\mathbf{1}$ & $4.990 \pm 0.207^{\mathrm{a}}$ & $3.825 \pm 0.150^{\mathrm{a}}$ & $4.026 \pm 0.089^{\mathrm{c}}$ \\
$\mathbf{1 . 5}$ & $4.990 \pm 0.219^{\mathrm{a}}$ & $3.825 \pm 0.150^{\mathrm{a}}$ & $2.867 \pm 0.621^{\mathrm{d}}$ \\
$\mathbf{S E M}$ & 0.096 & 0.194 & 0.278 \\
\hline
\end{tabular}

a-c: within a column, values not sharing the same superscript letter were considered as significantly different $(\mathrm{p}<0.05)$. SEM: Standard error of the mean

As it can be seen in Table 2, the increase in level of E. platyloba ethanolic extract addition led to a significant diminution in population of L. monocytogenes $(\log \mathrm{cfu} / \mathrm{g})$ for the Lighvan cheese samples at day 15 of ripening $(p<0.05)$.

Simultaneous increment in the levels of added E. platyloba ethanolic extract and time resulted in a statistically significant decrement in
L. monocytogenes population logarithm in Lighvan cheese $(p<0.05)$, whereas no significant influence on $\mathrm{pH}$ and salt concentration were observed ( $>0.05)$ (Table 3). L. monocytogenes was not detected for two treatments (at concentrations of $1 \%$ and $1.5 \%$ of E. platyloba ethanolic extract) at day 90 of the ripening.

Table 3. Interaction effects of different levels of E. platyloba ethanolic extract and ripening time on $\mathrm{pH}$, salt concentration and L. monocytogenes population (log $\mathrm{cfu} / \mathrm{g})$ in Lighvan cheese

\begin{tabular}{lccc}
\hline $\begin{array}{l}\text { Ethanolic extract level } \mathbf{( \% )} \\
\times \text { Time (Days) }\end{array}$ & $\mathbf{p H}$ & Salt concentration $\mathbf{( \% )}$ & $\begin{array}{c}\text { L. monocytogenes } \\
\text { population }\end{array}$ \\
\hline $\mathbf{0 . 0} \times \mathbf{1 5}$ & $4.965 \pm 0.107$ & $4.283 \pm 0.439$ & $5.736 \pm 0.116$ \\
$\mathbf{0 . 5} \times \mathbf{1 5}$ & $4.870 \pm 0.051$ & $3.975 \pm 0.100$ & $4.501 \pm 0.176$ \\
$\mathbf{1 . 0} \times \mathbf{1 5}$ & $4.990 \pm 0.207$ & $3.825 \pm 0.150$ & $4.206 \pm 0.089$ \\
$\mathbf{1 . 5} \times \mathbf{1 5}$ & $4.990 \pm 0.219$ & $3.825 \pm 0.150$ & $2.867 \pm 0.621$ \\
$\mathbf{0 . 0} \times \mathbf{3 0}$ & $4.890 \pm 0.092$ & $4.008 \pm 0.080$ & $5.835 \pm 0.103$ \\
$\mathbf{0 . 5} \times \mathbf{3 0}$ & $4.923 \pm 0.066$ & $4.401 \pm 0.210$ & $3.867 \pm 0.112$ \\
$\mathbf{1 . 0} \times \mathbf{3 0}$ & $5.103 \pm 0.311$ & $3.667 \pm 0.189$ & $3.402 \pm 0.084$ \\
$\mathbf{1 . 5} \times \mathbf{3 0}$ & $5.103 \pm 0.240$ & $3.667 \pm 0.167$ & $2.935 \pm 0.035$ \\
$\mathbf{0 . 0} \times \mathbf{6 0}$ & $4.985 \pm 0.114$ & $4.042 \pm 0.077$ & $3.841 \pm 0.076$ \\
$\mathbf{0 . 5} \times \mathbf{6 0}$ & $4.783 \pm 0.163$ & $3.833 \pm 0.099$ & $3.103 \pm 0.067$ \\
$\mathbf{1 . 0} \times \mathbf{6 0}$ & $4.957 \pm 0.076$ & $4.109 \pm 0.230$ & $2.735 \pm 0.029$ \\
$\mathbf{1 . 5} \times \mathbf{6 0}$ & $4.957 \pm 0.044$ & $4.102 \pm 0.241$ & $0.767 \pm 0.018$ \\
$\mathbf{0 . 0} \times \mathbf{9 0}$ & $4.771 \pm 0.209$ & $4.117 \pm 0.024$ & $1.914 \pm 0.045$ \\
$\mathbf{0 . 5} \times \mathbf{9 0}$ & $4.873 \pm 0.127$ & $3.933 \pm 0.069$ & $1.563 \pm 0.023$ \\
$\mathbf{1 . 0} \times \mathbf{9 0}$ & $4.917 \pm 0.284$ & $4.136 \pm 0.196$ & $0.000 \pm 0.000$ \\
$\mathbf{1 . 5} \times \mathbf{9 0}$ & $4.913 \pm 0.191$ & $4.133 \pm 0.144$ & $0.000 \pm 0.000$ \\
$\mathbf{S E M}$ & 0.196 & 0.384 & 0.542 \\
\hline $\mathbf{9} \mathbf{W}$ & & & \\
\hline
\end{tabular}

a-c: within a column, values not sharing the same superscript letter were considered as significantly different $(\mathrm{p}<0.05)$. SEM: Standard error of the mean 


\section{DISCUSSION}

The World Health Organization (WHO) has estimated that about $30 \%$ of people from industrialized nations suffer from foodborne illnesses annually (22). The results of most studies show that L. monocytogenes is widespread in most food products, especially in dairy foods (23). The presence of $L$. monocytogenes in traditional dairy products indicates the potential risk of infection with this bacterium in consumers. The presence of this pathogenic microorganism in traditional dairy products is of particular importance because it can be a health hazard especially for pregnant women, the elderly, infants, and immunocompromised people and the mortality rate in high-risk groups has been reported to be $20-75 \%$ (24).

The results of the current study showed that although during the manufacture of Lighvan cheese (90 days) the logarithm of L. monocytogenes population decreased in the absence of E. platyloba ethanolic extract $(\mathrm{p}>0.05)$, its enumeration was not lower than $80 \mathrm{cfu} / \mathrm{ml}$ even after 90 days of ripening. Similar results have also been reported by Mirzaei for Lighvan cheese (8). Ryser and Marth (25) reported that, during the first 14 to 28 days of ripening, the number of L. monocytogenes cells (cfu) increased in Cheddar cheese. This is not in agreement with the results of the present study. This evidence suggests that some growth of the organism may have occurred during the early stages of ripening in Cheddar cheese having a $\mathrm{pH}$ of 5-5.1. Almost the same result was observed for Lighvan cheese. The Mexican-style cheese was reported as a source for the California listeriosis outbreak in 1985, containing about 100-1,000 L. monocytogenes cells/g of cheese (25). Accordingly, it can be claimed that some samples of the Lighvan cheese manufactured in this study can cause illness (regardless of E. platyloba ethanolic extract) if they are consumed by susceptible individuals.

In the present study, E. platyloba ethanolic extract showed a significant bactericidal effect on L. monocytogenes in Lighvan cheese during the ripening time. As the concentration of ethanolic extract increased, its bactericidal activity on L. monocytogenes increased $(\mathrm{p}<0.05)$, as well. Boniadian et al. reported that ethanolic extract of E. platyloba DC showed an acceptable anti-listeria effect in milk compared to the control group $(\mathrm{p}<0.05)$. MIC and MBC for ethanolic extract of E. platyloba were reported $70 \mathrm{mg} / \mathrm{ml}$ and $100 \mathrm{mg} / \mathrm{ml}$, respectively. They also revealed that as the concentration of ethanolic extract increased,
L. monocytogenes population decreased significantly in the milk $(\mathrm{p}<0.05)(26)$. These results are in compliance with the findings obtained in our investigation. Sharafati-chaleshtori et al. (27) reported that both $\mathrm{MIC}$ and $\mathrm{MBC}$ of E. platyloba ethanolic extract for $L$. monocytogenes were $31.25 \mathrm{mg} / \mathrm{ml}$, but the value of $\mathrm{MIC}$ and $\mathrm{MBC}$ corresponding to the E. platyloba ethanolic extract for L. monocytogenes was found to be $2.5 \mathrm{mg} / \mathrm{ml}$ in the present study (in vitro). Entezari et al. (28) revealed that $30,000 \mathrm{mg} / \mathrm{ml}$ of E. platyloba methanolic extract causes inhibition of Pseudomonas aeruginosa and Staphylococcus aureus. It was reported that MIC and MBC of Echinophora cinerea essential oil for L. monocytogenes were 22 and $24 \mathrm{mg} / \mathrm{ml}$, respectively (29). The different results attained for antimicrobial effects of E. platyloba in various studies may be in association with the differences in the methods of preparation of the ethanolic extract, the concentrations and solvents used, the microbial strains, the method of evaluation of the antimicrobial effect, and the temperature of the environment.

The antimicrobial activity has also been attributed to the presence of some active constituents in the extract of E. platyloba such as stigmasterol and sitosterol (30). The mechanism of the antibacterial effect of plant extracts is related to their hydrophobic properties, which leads to the penetration of such compounds into the phospholipids membrane of bacteria, disrupting their structure, and increased permeability. This causes the inhibition and flow of ions and other cellular compounds that eventually lead to bacterial death (13). In food, major factors such as fats and proteins, water activity $\left(\mathrm{a}_{\mathrm{w}}\right)$, antioxidants, $\mathrm{pH}$, salt and external factors such as temperature, packaging and microorganism properties, can affect the antibacterial activity of the extract (13). According to the results of the current study, a concentration of $1.5 \%$ of E. platyloba ethanolic extract in Lighvan cheese can be considered as the best for the control of L. monocytogenes.

\section{CONCLUSION}

This study investigated the effect of E. platyloba ethanolic extract added as an antibacterial biocomponent in the Lighvan cheese aimed to control the population of $L$. monocytogenes. The addition of E. platyloba ethanolic extract did not lead to any significant changes in $\mathrm{pH}$ as well as the salt concentration of Lighvan cheese 
during the ripening time. As the concentration of added E. platyloba ethanolic extract increased, the logarithmic population of $L$. monocytogenes decreased. Accordingly, the best concentration of E. platyloba ethanolic extract which resulted in the complete destruction of $L$. monocytogenes was $1-1.5 \%$ and, in this respect, it was concluded that the best age for Lighvan cheese ripening was 90 days. The results of this work clearly showed that the addition of E. platyloba ethanolic extract can be a promising method for control of the L. monocytogenes population in Lighvan cheese. This could be a promising antibacterial, naturally derived compound that could be used by traditional cheese producers. According to similar studies, the use of E. platyloba ethanolic extract may also improve the sensory properties of Lighvan cheese, but further investigations should be conveyed to validate this claim. In this study, only the standard strain of L. monocytogenes was used in Lighvan cheese. It should be noted that the behavior and the virulence of different strains of this bacterium can also affect its survival time in Lighvan cheese. Both MIC and MBC of E. platyloba ethanolic extract would probably be different for each strain and, therefore, the optimal concentration of ethanolic extract for controlling the pathogens in Lighvan cheese may be different as well.

\section{CONFLICT OF INTEREST}

The authors declared that they have no potential conflict of interest with respect to the authorship and/or publication of this article.

\section{ACKNOWLEDGEMENTS}

This research was supported by the Maragheh Branch, Islamic Azad University.

\section{AUTHORS' CONTRIBUTIONS}

SG performed the research. SM designed and led the research and wrote the article. AY performed statistical analyzes of the research.

\section{REFERENCES}

1. Farkye, N.Y., Vedamuthu, E.R. (2002). Microbiology of soft cheeses. In: R.K. Robinson (Ed.), Dairy microbiology handbook, 3rd ed. (pp. 479-510). New York: Wiley-Interscience.

https://doi.org/10.1002/0471723959.ch10

2. Brooks, G.F., Carroll, K.C., Butel, J.C., Morse, S.A., Mietzaner, T.A. (2013). Jawetz, Melnick \& Adelberg's medical microbiology, 26th ed. (pp. 187-195). New York: McGraw-Hill.

3. Loncarevic, S., Danielsson-Tham, M.L., Tham, W. (1995). Occurrence of Listeria monocytogenes in soft and semi-soft cheeses in retail outlets in Sweden. Int J Food Microbiol. 26(2): 245-250. https://doi.org/10.1016/0168-1605(95)00105-S

4. Rudol, M., Scherer, S. (2001). High incidence of Listeria monocytogenes in European red smear cheese. Int J Food Microbiol. 63(1-2): 91-98. https://doi.org/10.1016/S0168-1605(00)00413-X

5. Mansuri Najand, L., Ghanbarpour, R. (2006). A study on enteropathogenic Escherichia coli isolated from domestic Iranian soft cheese. Vet Arhiv. 76(6): 531-536.

6. Abdimoghadam, Z., Shamloo, E., Mortazaivan, A.M., Atefi, M. (2015). Frequency of Listeria species in raw milk and traditional dairy products in Isfahan, Iran. Iran J Nutrition Sci Food Technol. 10(3): 101-107.

7. Khedmati Morasa, H., Mahmoudi, R., Ghajarbeygi, P., Mosavi, S., Shahsavari, S., Abbasi, N., Sarfalah, N. (2019). Listeria monocytogenes contamination in unpasteurized traditional cheese products in Qazvin, Iran. J Mazandaran Univ Med Sci. 29(178): 115-126.

8. Mirzaei, H. (2011). Microbiological changes in Lighvan cheese throughout its manufacture and ripening. AJMR 5(13): 1609-1614. https://doi.org/10.5897/AJMR11.111

9. Mirzaei, H., Karim, G., Ghiasi Khosroshahi, A. (2008). The microbiological and chemical quality of traditional Lighvan cheese (white cheese in brine) produced in Tabriz, Iran. J Anim Vet Adv. 7(12): 1594-1599.

10. Cetinkaya, F., Soyatemiz, G.E. (2006). Microbiological and chemical changes throughout the manufacture and ripening of kashar: a traditional Turkish cheese. Turk J Vet Anim Sci. 30, 397-404.

11. Zeinhoma, M.M.A., Abdel-Latef, G.K. (2014). Public health risk of some milk borne pathogens. BJBAS 3(3): 209-215.

https://doi.org/10.1016/j.bjbas.2014.10.006 
12. Salimpour, F., Mazooji, A., Mazhar, F., Barzin, G. (2014). Comparative study of antibacterial properties of four species of Salvia L. as a medicinal plant. Res Med. 37(4): 205-210.

13. Burt, S. (2004). Essential oils: their antibacterial properties and potential applications in foods a review. Int J Food Microbiol. 94(3): 223-253. https://doi.org/10.1016/j.ijfoodmicro.2004.03.022 PMid:15246235

14. Avijgan, M., Saadat, M., Nilforooshzadeh, M.A., Hafizi, M. (2006). Antifungal effect of Echinophora platyloba extract on some common dermatophytes. J Med Plants. 5(18): 10-16.

15. Asghari, G.R., Sajjadi, S.E., Sadraei, H., Yaghobi, K.H. (2003). Essential oil constituents of Echinophora platyloba DC. IJPR 2(3): 185-186.

16. Jamshidi, M., Ahmadi-Ashtiani, H.R., Rezazadeh, S., Fathiazad, F., Mazandarani, M., Khaki, A. (2010). Study on phenolics and antioxidant activity of some selected plants of Mazandaran province. J Med Plants. 9(34): 177- 182.

17. Oroujalian, F., Kasra-Kermanshahi, R., Azizi, M., Basami, M.R. (2010). Synergistic antibacterial activity of the essential oils from three medicinal plants against some important food-borne pathogens by microdilution method. Iran J Med Aroma Plants. 2(2):133-146.

http://doi: 10.22038/nmj.2017.04.006

18. Mahdavi, S., Amiradalat, M., Babashpour, M., Sheikhlooei, H., Miransari, M. (2020). The antioxidant, anticarcinogenic and antimicrobial properties of Verbascum thapsus L. Med Chem. 16(7): 991-995.

https://doi.org/10.2174/1573406415666190828155951 PMid:31456524

19. AOAC. (2000). Official Methods of Analysis. Association of Official Analytical Chemists. 17th ed., Gaithersburg. MD, USA.

20. Rashid, M., Miyamoto, T. (2005). Quality evaluation of traditional milk "Sahi” in Bangladesh. J Milk Sci. 54(1): 29-36.

21. Lynch, J.M., Barbano, D.M. (1999). Kjeldahl nitrogen analysis as a reference method for protein determination in dairy products. J AOAC Int. 82(6): 1389-1398.

https://doi.org/10.1093/jaoac/82.6.1389

PMid:10589493
22. WHO. Food safety and Foodborne Illness. World Health Organization. Fact sheet 237, revised January 2002 - Geneva.

23. Kargar, M., Ghasemi, A. (2007). A survey on prevalence rate \& antibiotic resistance of Listeria monocytogenes in fresh cheese of Marvdasht. J Food Technol Nutr. 3(31): 72-77.

24. Swaminathan, B., Gerner-Smidt, P. (2007). The epidemiology of human listeriosis. Microb Infect. 9(10): 1236-1243.

https://doi.org/10.1016/j.micinf.2007.05.011

PMid:17720602

25. Ryser, E.T., Marth, E.H. (1987). Behavior of Listeria monocytogenes during the manufacture and ripening of Cheddar cheese. J Food Prot. 50(1): 7-13. https://doi.org/10.4315/0362-028X-50.1.7 PMid:30965530

26. Boniadian, M., Rouzkhosh, T., Moshtaghi, H. (2018). Anti listeria effects of Echinophora platyloba DC. extracts in broth medium and milk. IJMAPR 34(3): 391-400.

27. Sharafati-chaleshtori, R., Rafieian-kopaei, M., Mortezaei, S., Sharafati-chaleshtori, A., Amini, E. (2012). Antioxidant and antibacterial activity of the extracts of Echinophora platyloba D.C. Afr J Pharm Pharmacol. 6(37): 2692-2695.

28. Entezari, M., Hashemi, M., Ashki, M., Ebrahimian, S., Bayat, M., Azizi Saraji, A.R., Rohani, S.R. (2009). Studying the effect Echinophora platyloba extract on bactira (Staphilococus aureus and Pseudomonas aeroginosa) and fungi (Candidia albicans, Aspergilus flavus and Aspergilus niger) in vitro. World J Med Sci. 4(2):89-92.

29. Pass, M., Rashidipour, M., Talei, G.R., Doosty, B. (2012). Chemical compositions, antibacterial and antioxidant properties of Echinophora cinerea essential oil. J Herb Drug. 3(2): 67-74.

30. Valizadeh, H., Mahmoodi, K.F., Alizadeh, Z., Bahadori, M.B. (2014). Isolation and structure elucidation of secondary metabolites from Echinophora platyloba DC from Iran. J Med Plants. 13(49): 15-21. 